\title{
Urolithiasis
}

\section{Interleukin-1 $\beta$, Calcium-Sensing Receptor, and Urokinase Gene Polymorphisms in Korean Patients with Urolithiasis}

\author{
Joon-Young Kim, Young-Sun Kim, In-Ho Jang, Jae-Dong Jung, Tae-Hyoung Kim, Hye-Ryun Kim ${ }^{1}$ \\ Departments of Urology and ${ }^{1}$ Laboratory Medicine, College of Medicine, Chung-Ang University, Seoul, Korea
}

\begin{abstract}
Purpose: There are various causes of ureter calculi, and genetic factors are known to play a role. Interleukin-1 (IL-1 $\beta$ ) and calcium-sensing receptor (CaSR) genes are related to hypercalciuria, and urokinase is related to the formation of calcium oxalate stones. This study investigated polymorphisms in IL-1 $\beta$, CaSR, and urokinase in patients with urolithiasis and healthy controls.

Materials and Methods: Urolithiasis patients treated at Chung-Ang University Hospital were enrolled from January 2007 to December 2008. The control group of volunteers displayed normal urinalysis findings in the health screening, no stones identified by ultrasonography, and no history of urolithiasis. DNA extracted from peripheral blood was analyzed by the polymerase chain reaction. Patients were genetically screened for mutations in IL-1 $\beta$ (484 urolithiasis patients, 208 controls), CaSR (433 urolithiasis patients, 197 controls), and urokinase (370 urolithiasis patients, 167 controls). Stone metabolic study was done to see the differences between the metabolic factors and to discern normal genes from polymorphic genes.

Results: According to the genotype frequency and allele frequency analysis, there were no statistically significant differences between IL-1 $\beta$, CaSR, and urokinase genes. Also, the analysis between genotypes and metabolic factors did not show statistically significant differences between the three genes.

Conclusions: In Korean urolithiasis patients, IL-1 $\beta$, CaSR, and urokinase gene polymorphisms do not differ from those of healthy individuals. A larger-scale study is needed to confirm the need for other genetic markers of urolithiasis.
\end{abstract}

Key Words: Calcium sensing receptor; Genetic polymorphism; Interleukin-1beta; Urokinase; Urolithiasis

This is an Open Access article distributed under the terms of the Creative Commons Attribution Non-Commercial License (http://creativecommons.org/licenses/by-nc/3.0) which permits unrestricted non-commercial use, distribution, and reproduction in any medium, provided the original work is properly cited.

\author{
Article History: \\ received 24 January, 2011 \\ accepted 21 April, 2011
}

\author{
Corresponding Author: \\ Tae-Hyoung Kim \\ Department of Urology, College of \\ Medicine, Chung-Ang University \\ 224-1, Heukseok-dong, \\ Dongjak-gu, Seoul 156-755, Korea \\ TEL: +82-2-6299-1785 \\ FAX: +82-2-6294-1406 \\ E-mail:kthlmk@hanafos.com \\ This work was supported by a Korea \\ Research Foundation Grant funded by \\ the Korean Government (MOEHRD, \\ Basic Research Promotion Fund) \\ (KRF-2008-331-E00238).
}

\section{INTRODUCTION}

Various causes determine the formation of ureter calculi, and genetic factors are known to play a role. Studies have tried to identify genes related to ureter calculi in an effort to clarify the cause of urolithiasis and to advance the diagnosis and treatment of urolithiasis [1,2]. In other studies, the use of single-nucleotide polymorphisms (SNPs) associated with genetic diseases has been fruitful in identifying candidate disease genes. Recent genetic advances in urolithiasis indicate the potential of a new approach towards the gene polymorphism [3-7].
Interleukin-1 $\beta$ (IL-1 $\beta$ ) is a potent proinflammatory agent that can induce bone resorption, osteoclast formation, and hypercalciuria. The calcium-sensing receptor $(\mathrm{CaSR})$ regulates cellular calcium homeostasis and controls parathyroid hormone secretion that is controlled by urinary calcium absorption. Urokinase functions to degrade the organic matrix of nascent urinary stones, preventing their full formation and growth. Hypothesizing that these genes might be crucial in urolithiasis, the present study examined gene polymorphisms in IL-1 $\beta$, CaSR, and urokinase in Korean urolithiasis patients and healthy controls. 


\section{MATERIALS AND METHODS}

\section{Subjects}

From January 2007 to December 2008, patients who had a confirmed diagnosis after a radiological exam, such as computed tomography, intravenous pyelography, or kidney ultrasonography, and who were treated for urolithiasis with open surgery, ureterorenoscopic lithotripsy, extracorporeal shock wave lithotripsy, or conservative treatment at Chung-Ang University Hospital were involved in this study. Informed consent for genetic testing was given by those who agreed to participate. The control group consisted of patients displaying normal urinalysis findings from the health screening, absence of stones as identified by ultrasonography, and no history of urolithiasis. Genetic testing was performed as described below to detect polymorphisms in IL-1 $\beta$ (484 urolithiasis patients, 208 controls), CaSR (433 urolithiasis patients, 197 controls), and urokinase (370 urolithiasis patients, 167 controls). The study protocol was approved by the Chung-Ang University Institutional Review Board.

\section{Methods}

1) Genomic DNA isolation: Genomic DNA was isolated from peripheral blood leukocytes in EDTA-containing tubes. All processes were done according to the manufacturer's instructions by use of the Wizard Genomic DNA Purification Kit (Promega, Madison, WI, USA).

2) Amplification and confirmation of each mutation (Fig. 1)

(1) $\mathbf{L}-\mathbf{1} \beta$ T/C: The extracted DNA was amplified by polymerase chain reaction (PCR) with the forward primer 5 $-\mathrm{G}$ CCTGAACCCTGCATACCGT-3' and the reverse primer 5'-GCCAATAGCCCTCCCTGTCT-3'. PCR procedures were carried out in a total volume of $20 \mu$ l containing genomic DNA, each primer, and Taq DNA polymerase. PCR amplification was performed in a programmable thermal cycler GeneAmp PCR system 9700 (Applied Biosystems, Foster City, CA, USA). The cycling conditions for IL-1 $\beta T / C$ polymorphism were 1 cycle at $95^{\circ} \mathrm{C}$ for 5 minutes; 35 cycles at $94^{\circ} \mathrm{C}$ for 30 seconds, $56^{\circ} \mathrm{C}$ for 30 seconds, and $72^{\circ} \mathrm{C}$ for 30 seconds; and a final cycle at $72^{\circ} \mathrm{C}$ for 10 minutes. Then, $5 \mu \mathrm{l}$ of the product was loaded onto $3 \%$ agarose gel plates containing ethidium bromide for electrophoresis. The 155-bp
PCR product was mixed with $10 \mathrm{U} / \mu \mathrm{l}$ of $A v a \mathrm{I}$ restriction enzyme (Enzynomics, Daejeon, Korea) and the restriction buffer according to the manufacturer's instructions. The thymine in the wild-type sequence is replaced by cytosine as the polymorphic mutation, generating a recognition site for AvaI. The resulting digestion generates 88-bp and 68-bp fragments.

(2) CaSR: A986S: Primers were designed to amplify the region containing the A986S polymorphism (forward primer 5'-CTTTGATGAGCCTCAGAAGAGC-3' and reverse primer 5'-ACAACTCTTCAGGGTCCTCC-3'). The PCR cycling condition for CaSR gene polymorphism was 1 cycle at $95^{\circ} \mathrm{C}$ for 5 minutes; 35 cycles at $94^{\circ} \mathrm{C}$ for 30 seconds, $58^{\circ} \mathrm{C}$ for 30 seconds, and $72^{\circ} \mathrm{C}$ for 45 seconds; and a final cycle at $72^{\circ} \mathrm{C}$ for 7 minutes. The 218 -bp PCR product was mixed with $20 \mathrm{U} / \mu \mathrm{l}$ of $\mathrm{SacI}$ restriction enzyme (Enzynomics) and the restriction buffer according to the manufacturer's instructions. SacI would recognize a recognition site in the mutant allele producing fragments of 218-bp and 198-bp.

(3) Urokinase 3' untranslated region (UTR): The extracted DNA was PCR-amplified by using the forward primer 5'-C CGCAGTCACACCAAGGAAGAG-3' and the reverse primer 5'-GCCTGAGGGTAAAGCTATTGTCGTGCAC-3'. The PCR cycling condition for the urokinase 3' UTR polymorphism was 1 cycle at $94^{\circ} \mathrm{C}$ for 5 minutes; 35 cycles at $94^{\circ} \mathrm{C}$ for 30 seconds, $58^{\circ} \mathrm{C}$ for 30 seconds, and $72^{\circ} \mathrm{C}$ for 40 seconds; and a final cycle at $72^{\circ} \mathrm{C}$ for 7 minutes. The 210 -bp PCR product was mixed with $20 \mathrm{U} / \mu \mathrm{l}$ of ApaL1 restriction enzyme and the restriction buffer according to the manufacturer's instructions. Polymorphism would generate an enzyme recognition site, and digestion would produce fragments of 185bp and 25-bp.

3) Stone metabolic study: IL-1 $\beta$, CaSR, and urokinase polymorphisms were determined in the urolithiasis patients. Each genotype was classified into groups and the average sodium, calcium, citrate, and oxalate concentrations in urine collected for over 24 hours were determined, as was the 24-hour urine volume.

4) Statistics: The chi-square test was used for the statistical analysis of gene frequency and allele frequency, and oneway ANOVA was used for the statistical analysis of metabolic factors between the three genes. SPSS ver. 12.0 (SPSS Inc., Chicago, IL, USA) was used, with p-values less than
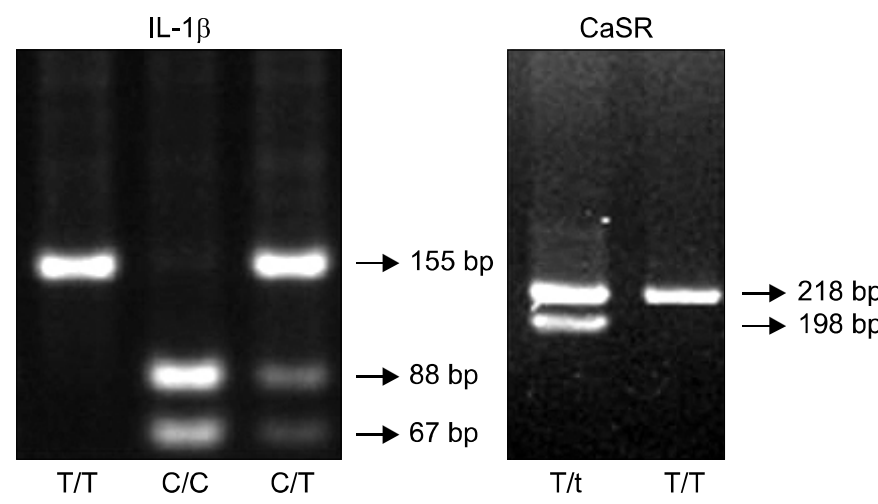

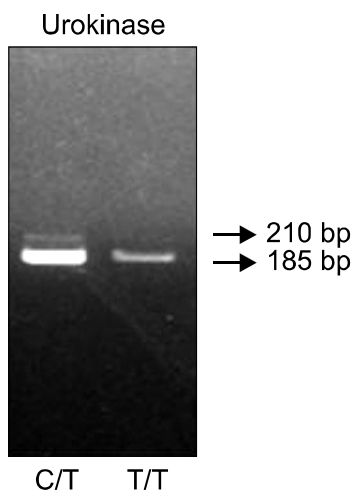

FIG. 1. Representative agarose gel electrophoresis illustrating the restriction fragment length polymorphism products for the polymorphisms of the three examined genes. IL-1 $\beta$ : T allele cut generated 155-bp fragments and the $\mathrm{C}$ allele cut generated 88- and 67-bp fragments. CaSR: $\mathrm{T}$ allele cut generated 218-bp fragments and the $t$ allele cut generated 198-bp fragments. Urokinase: $\mathrm{T}$ allele cut generated 185 -bp fragments and the $\mathrm{C}$ allele cut generated 210-bp fragments. 
0.05 considered significant.

\section{RESULTS}

\section{Genotype frequency}

In urolithiasis patients, the $C / C, C / T$, and $T / T$ IL- $1 \beta$ gene

TABLE 1. Gene and allele frequencies of interleukin-1 $\beta$ in urolithiasis patients and healthy controls

\begin{tabular}{|c|c|c|c|}
\hline & $\begin{array}{l}\text { Urolithiasis patients }(\%) \\
\qquad(\mathrm{n}=484)\end{array}$ & $\begin{array}{l}\text { Control }(\%) \\
(\mathrm{n}=208)\end{array}$ & p-value \\
\hline \multicolumn{4}{|c|}{ Gene frequency } \\
\hline$C C$ & $61(12.6)$ & 33 (15.9) & $>0.05$ \\
\hline$C T$ & $282(58.3)$ & $123(59.1)$ & $>0.05$ \\
\hline$T T$ & $141(29.1)$ & $52(25)$ & $>0.05$ \\
\hline \multicolumn{4}{|c|}{ Allele frequency } \\
\hline$T$ & $564(58.3)$ & $227(54.6)$ & $>0.05$ \\
\hline$C$ & $404(41.7)$ & $189(45.4)$ & $>0.05$ \\
\hline
\end{tabular}

TABLE 2. Gene and allele frequencies of calcium-sensing receptor gene in urolithiasis patients and healthy controls

\begin{tabular}{|c|c|c|c|}
\hline & $\begin{array}{l}\text { Urolithiasis patients }(\%) \\
\qquad(\mathrm{n}=433)\end{array}$ & $\begin{array}{l}\text { Control }(\%) \\
(\mathrm{n}=197)\end{array}$ & p-value \\
\hline \multicolumn{4}{|c|}{ Gene frequency } \\
\hline$T T$ & $415(95.9)$ & $191(97)$ & $>0.05$ \\
\hline$T t$ & $18(4.1)$ & $6(3)$ & $>0.05$ \\
\hline \multicolumn{4}{|c|}{ Allele frequency } \\
\hline$T$ & $848(98)$ & $388(98.5)$ & $>0.05$ \\
\hline$t$ & $18(2)$ & $6(1.5)$ & $>0.05$ \\
\hline
\end{tabular}

TABLE 3. Gene and allele frequencies of urokinase gene in urolithiasis patients and healthy controls

\begin{tabular}{lcrl}
\hline & $\begin{array}{c}\text { Urolithiasis patients } \\
(\%)(\mathrm{n}=370)\end{array}$ & $\begin{array}{c}\text { Control }(\%) \\
(\mathrm{n}=167)\end{array}$ & $\mathrm{p}$-value \\
\hline Gene frequency & & & \\
$C T$ & $212(57.3)$ & $104(62.3)$ & $>0.05$ \\
$T T$ & $158(42.7)$ & $63(37.7)$ & $>0.05$ \\
Allele frequency & & & \\
$T$ & $528(71.3)$ & $230(68.9)$ & $>0.05$ \\
$C$ & $212(28.7)$ & $104(31.1)$ & $>0.05$ \\
\hline
\end{tabular}

polymorphisms were detected in 61 (12.6\%), $282(58.3 \%)$, and 141 patients $(29.1 \%)$, respectively. The respective proportions in the normal controls were 33 (15.9\%), 123 $(59.1 \%)$, and 52 patients (25\%) (Table 1). In urolithiasis patients, the $T / T$ and $T / t$ CaSR gene polymorphisms were detected in $415(95.9 \%)$ and 18 patients $(4.1 \%)$, respectively. The respective proportions in the normal controls were 191 patients $(97 \%)$ and 6 patients (3\%) (Table 2$)$. In urolithiasis patients, the $C / T$ and $T / T$ urokinase gene polymorphisms were detected in $212(57.3 \%)$ and 158 patients $(42.7 \%)$, respectively. The respective proportions in the normal controls were $104(62.3 \%)$ and 63 patients $(37.7 \%)$ (Table 3). No statistically significant differences were evident between the patient groups and the control

TABLE 5. Laboratory findings in urolithiasis patients according to calcium-sensing receptor gene variation

\begin{tabular}{lccc}
\hline \multirow{2}{*}{ Category } & \multicolumn{2}{c}{ CaSR } & p-value \\
\cline { 2 - 3 } & $T T$ & $T t$ & \\
\hline $\mathrm{uNa}$ & $215.9 \pm 180.5$ & $134.2 \pm 41.8$ & $\mathrm{NS}$ \\
$\mathrm{uCa}$ & $190.3 \pm 112.0$ & $138.6 \pm 84.0$ & $\mathrm{NS}$ \\
$\mathrm{Citrate}$ & $334.9 \pm 222.9$ & $276.7 \pm 163.1$ & $\mathrm{NS}$ \\
Oxalate & $37.9 \pm 20.8$ & $22.4 \pm 15.0$ & $\mathrm{NS}$ \\
Urine vol & $2,675.0 \pm 1,542.5$ & $1,670 \pm 887.0$ & $\mathrm{NS}$ \\
\hline
\end{tabular}

NS: not significant. Normal range: urine $\mathrm{Na}(0-200 \mathrm{mEq})$, urine $\mathrm{Ca}(0-250 \mathrm{mg})$, citrate ( $>320 \mathrm{mg})$, oxalate $(0-45 \mathrm{mg})$, urine volume $(>2,000 \mathrm{ml})$. uNa: sodium in urine. $\mathrm{uCa}$ : calcium in urine

TABLE 6. Laboratory findings in urolithiasis patients according to urokinase gene variation

\begin{tabular}{lccc}
\hline \multirow{2}{*}{ Category } & \multicolumn{2}{c}{ Urokinase } & p-value \\
\cline { 2 - 3 } & $C T$ & $T T$ & \\
\hline $\mathrm{uNa}$ & $276.4 \pm 377.9$ & $203.2 \pm 108.5$ & $\mathrm{NS}$ \\
$\mathrm{uCa}$ & $177.7 \pm 121.5$ & $197.6 \pm 118.8$ & $\mathrm{NS}$ \\
$\mathrm{Citrate}$ & $273.1 \pm 196.4$ & $335.3 \pm 243.1$ & $\mathrm{NS}$ \\
Oxalate & $37.8 \pm 17.7$ & $37.1 \pm 19.2$ & $\mathrm{NS}$ \\
Urine vol & $2,500.0 \pm 2,751.8$ & $2,751.8 \pm 1,645.5$ & $\mathrm{NS}$ \\
\hline
\end{tabular}

NS: not significant. Normal range: urine $\mathrm{Na}(0-200 \mathrm{mEq})$, urine $\mathrm{Ca}(0-250 \mathrm{mg})$, citrate $(>320 \mathrm{mg})$, oxalate $(0-45 \mathrm{mg})$, urine volume $(>2,000 \mathrm{ml})$. uNa: sodium in urine. uCa: calcium in urine

TABLE 4. Laboratory findings in urolithiasis patients according to interleukin-1 $\beta$ gene variation

\begin{tabular}{|c|c|c|c|c|}
\hline \multirow{2}{*}{ Category } & \multicolumn{3}{|c|}{ Interleukin-1 $\beta$} & \multirow{2}{*}{$\mathrm{p}$-value } \\
\hline & $C C$ & $C T$ & $T T$ & \\
\hline $\mathrm{uNa}$ & $248.1 \pm 387.6$ & $195.05 \pm 98.1$ & $218.6 \pm 109.9$ & NS \\
\hline $\mathrm{uCa}$ & $154.3 \pm 102.6$ & $194.9 \pm 111.7$ & $196.3 \pm 196.2$ & NS \\
\hline Citrate & $278.2 \pm 186.8$ & $358.1 \pm 269.4$ & $333.8 \pm 210.0$ & NS \\
\hline Oxalate & $37.9 \pm 20.5$ & $37.9 \pm 20.5$ & $37.8 \pm 20.3$ & NS \\
\hline Urine vol & $2,615.7 \pm 1,347.2$ & $2,615.6 \pm 1,347.3$ & $2,931.1 \pm 1,721.7$ & NS \\
\hline
\end{tabular}

NS: not significant. Normal range: urine $\mathrm{Na}(0-200 \mathrm{mEq})$, urine $\mathrm{Ca}(0-250 \mathrm{mg})$, citrate ( $>320 \mathrm{mg})$, oxalate $(0-45 \mathrm{mg})$, urine volume $(>2,000 \mathrm{ml}) . \mathrm{uNa}$ : sodium in urine. $\mathrm{uCa}$ : calcium in urine 
groups for any of the genes.

\section{Allele frequency}

The $\mathrm{C}$ and T IL-1 $\beta$ allele frequencies in the 484 urolithiasis patients were 404 patients $(41.7 \%)$ and 564 patients $(58.3 \%)$, respectively. The respective proportions of the 208 control patients were 189 patients $(45.4 \%)$ and 227 patients $(54.6 \%)$. The $T$ and $t$ CaSR allele frequencies in 433 urolithiasis patients were 848 patients $(98 \%)$ and 18 patients $(2 \%)$. The respective proportions of the 197 normal controls were 388 patients $(98.5 \%)$ and 6 patients $(1.5 \%)$. The $T$ and $C$ urokinase allele frequencies in the 370 urolithiasis patients were 528 patients $(71.3 \%)$ and 212 patients $(28.7 \%)$, respectively. The respective proportions in the 167 normal controls were 230 patients $(68.9 \%)$ and 104 patients $(31.1 \%)$. No statistically significant differences were evident between the patient groups and the control groups for any of the genes.

\section{Genotyping and laboratory findings}

IL-1 $\beta$, CaSR, and urokinase genotypes of the urolithiasis patients (Table 4-6, respectively) were compared with the means of laboratory findings. No significant differences were apparent.

\section{DISCUSSION}

Genetic factors influence the formation of urinary calculi. For example, the formation of urinary calcium stones, urinary calcium and hydroxyl concentrations, crystallization growth factors, and inhibitory factors are affected by genetic factors [8]. In addition, calcium oxalate stones have been linked to a polygenic defect [2]. Also, there is a report that hypercalciuria and urolithiasis are related. However, genetic details of hypercalciuria and urolithiasis patients are unclear; thus, it remains unresolved whether one or several genes are involved in calculi formation [8].

For a disease such as urolithiasis, which results from the complex interaction of multiple factors, determination of SNPs is useful to identify disease-related gene(s). The complete roster of polymorphic markers must be resolved with the need to identify $90 \%$ or more of the relevant SNPs. SNPs differ appreciably with race, although about $30 \%$ are common between all races. Much SNP research has been done in other countries, but none in Korea. In the present study, we aimed to determine SNPs in Korean patients.

IL-1 $\beta$ functions to localize the bone marrow macrophage to the site of inflammation, to stimulate differentiation of macrophages into osteoclasts by activation around the bone, and to cause hypercalciuria [9]. Similar to the present results, a study of IL-1 $\beta$ polymorphism conducted in China on patients with calcium oxalate stones did not find evidence of a statistically significant association of the polymorphism with the patient group [10]. A study in India reported a significantly higher risk for urolithiasis in patients with a combination of high IL-1 $\beta$ and low IL-1 receptor antagonist genotypes [11]. This is consistent with the aforementioned racial difference in gene polymorphism. It seems that research on genetic factors to determine why there are low relations between IL-1 $\beta$ and urolithiasis in Asians is needed. In the present study, we compared the laboratory results of 24-hour collected urinary sodium, calcium, hydroxyl, and citric acid and urine volume according to each genotype. No significant differences were revealed. CaSR gene inactivation caused by mutations is associated with diseases characterized by hypocalciuria and hypercalcemia because gene inactivation causes changes in parathyroid hormone secretion and calcium reabsorption of tubular cells. CaSR gene mutation also seems to be the cause of idiopathic hypercalciuria, which is a risk factor for calcium renal stone formation and is characterized by an increase in calcium excretion even when normal plasma calcium ion is maintained [10,12,13]. A study from Brazil reported that CaSR polymorphism was overrepresented in hypercalciuric stone formers but that urinary calcium excretion was not associated with polymorphism [14]. Presently, CaSR gene polymorphism analysis did not reveal genotype differences between urolithiasis patients and normal controls. When allele frequency was classified into $T$ and $t$, no statistically significant difference was found, in agreement with the study of Italian urolithiasis patients (although statistical differences in CaSR mutations and hypercalciuira were reported) [15]. Likewise, the laboratory results of 24-hour urinary sodium, calcium, hydrox$\mathrm{yl}$, and citric acid and urine volume were compared according to each genotype, and again no significant differences were revealed. Urokinase was originally isolated from human urine, but is present in several physiological locations, such as the bloodstream and the extracellular matrix. The primary physiological substrate of the enzyme is plasminogen, which is an inactive zymogen form of the serine protease plasmin. It is assumed that urokinase breaks the organic matrix of nascent urinary stones, preventing their complete formation and growth. In a study of urolithiasis urokinase gene polymorphism conducted on patients in China, $T$ allele carriers had a statistically higher incidence of calcium oxalate stones [16]. A study from India also reported a significant difference in the distribution of the urokinase gene $C / T$ polymorphism between patients with stones and controls [17]. In the present study, the urokinase gene polymorphism analysis showed no genotype differences between urolithiasis patients and normal controls in the prevalence of the $C$ and $T$ alleles, which may reflect racial differences. Likewise, there were no statistically significant differences in urine parameters.

\section{CONCLUSIONS}

Polymorphisms of IL-1 $\beta$, CaSR, and urokinase did not significantly differ in Korean urolithiasis patients from those of a control group. A larger-scale study is needed to confirm the need for other genetic markers of urolithiasis. 


\section{Conflicts of Interest}

The authors have nothing to disclose.

\section{REFERENCES}

1. Danpure CJ. Genetic disorders and urolithiasis. Urol Clin North Am 2000;27:287-99.

2. McGeown MG. Inheritance of calcium renal stones. Lancet 1968;1:866.

3. Resnick M, Pridgen DB, Goodman HO. Genetic predisposition to formation of calcium oxalate renal calculi. N Engl J Med 1968;278:1313-8.

4. Goodman HO, Holmes RP, Assimos DG. Genetic factors in calcium oxalate stone disease. J Urol 1995;153:301-7.

5. Chen WC, Wu HC, Lin WC, Wu MC, Hsu CD, Tsai FJ. The association of androgen- and oestrogen-receptor gene polymorphisms with urolithiasis in men. BJU Int 2001;88:432-6.

6. Chen WC, Wu HC, Chen HY, Wu MC, Hsu CD, Tsai FJ. Interleukin-1beta gene and receptor antagonist gene polymorphisms in patients with calcium oxalate stones. Urol Res 2001;29:321-4.

7. Chen WC, Chen HY, Wu JY, Chen YT, Tsai FJ. Osteocalcin gene Hind III polymorphism is not correlated with calcium oxalate stone disease. Urol Res 2001;29:98-101.

8. Jackman SV, Kibel AS, Ovuworie CA, Moore RG, Kavoussi LR, Jarrett TW. Familial calcium stone disease: TaqI polymorphism and the vitamin D receptor. J Endourol 1999;13:313-6.

9. Hofbauer LC, Lacey DL, Dunstan CR, Spelsberg TC, Riggs BL,
Khosla S. Interleukin-1beta and tumor necrosis factor-alpha, but not interleukin-6, stimulate osteoprotegerin ligand gene expression in human osteoblastic cells. Bone 1999;25:255-9.

10. Hebert SC. Extracellular calcium-sensing receptor: implications for calcium and magnesium handling in the kidney. Kidney Int 1996;50:2129-39.

11. Mittal RD, Bid HK, Manchanda PK, Kapoor R. Association of interleukin-1beta gene and receptor antagonist polymorphisms with calcium oxalate urolithiasis. J Endourol 2007;21:1565-70.

12. Coe FL, Parks JH, Moore ES. Familial idiopathic hypercalciuria. N Engl J Med 1979;300:337-40.

13. Breslau NA, Coe FL. Management of idiopathic hypercalciuria. In: Coe FL, Favus MJ, Pak CY, Parks JH, Preminger GM, editors. Kidney stones: medical and surgical management. Philadelphia: Lippincott Williams \& Wilkins; 1996;773-85.

14. Ferreira LG, Pereira AC, Heilberg IP. Vitamin D receptor and calcium-sensing receptor gene polymorphisms in hypercalciuric stone-forming patients. Nephron Clin Pract 2010;114:c135-44.

15. Vezzoli G, Tanini A, Ferrucci L, Soldati L, Bianchin C, Franceschelli $\mathrm{F}$, et al. Influence of calcium-sensing receptor gene on urinary calcium excretion in stone-forming patients. J Am Soc Nephrol 2002;13:2517-23.

16. Tsai FJ, Lin CC, Lu HF, Chen HY, Chen WC. Urokinase gene 3'UTR T/C polymorphism is associated with urolithiasis. Urology 2002;59:458-61 .

17. Mittal RD, Bid HK, Kumar A, Bhandari M. Association of urokinase 3'-UTR polymorphism with calcium oxalate nephrolithiasis. J Endourol 2006;20:157-60. 